\title{
Konsumsi rokok dan asupan zat gizi balita pada rumah tangga miskin
}

\author{
Cigarette consumption and nutrient intake of toddlers in poor household
}

Winda Irwanti ${ }^{1}$, Madarina Julia ${ }^{2}$, Yayi Suryo Prabandari ${ }^{3}$

\begin{abstract}
Background: Eradication of poverty and starvation is still an agenda of Millennium Development Goals (MDGs) 2015 due to the serious impact of poverty and starvation to human beings. Poverty and starvation are worsened by smoking habit of the Indonesian population. Expenditures used for cigarettes may bring bad impact to the health of toddlers, including lack of nutrient intake. However, until today it is not yet precisely known how much lack of nutrient intake in toddlers caused by cigarette consumption.

Objective: To identify difference in nutrient intake of energy and protein of toddlers based on the amount of cigarettes consumed in poor household at Yogyakarta Municipality.

Method: The study used cross sectional design. Subject consisted of 86 toddlers of two-five years living in poor household at Yogyakarta Municipality. Cigarette consumption, mother of toddlers and all members of the family were obtained from interview. Method to assess intake was multiple 24 hours food recall within four days, whereas interview was used to assess cigarette consumption. Statistical analysis was performed by using Two Sample Independent t-test, Mann-Whitney U-test, regression, and Chi-Square.

Results: As much as $77.9 \%$ of poor household had at least one smoker. There was no significant difference in intake of energy and protein of toddlers living with smokers and non smokers, though percentage of expenditure for food was significantly lower in the household with smokers. This might be due to high consumption of food with high energy density at affordable price and protein at low price. Snacks were the third most consumed by toddlers and $40 \%$ of animal protein consumed were eggs.

Conclusion: There was no significant difference in intake of energy and protein of toddlers living in the poor household with smokers and those living with non smokers, but percentage of expenditure for food significantly lower in household with smokers.
\end{abstract}

KEY WORDS: poor household, cigarette, nutrient intake, toddlers, smokers, non smokers

\begin{abstract}
ABSTRAK
Latar belakang: Pemberantasan kemiskinan dan kelaparan menjadi salah satu agenda Millenium Development Goals (MDG's) 2015. Kemiskinan dan kelaparan diperparah dengan kebiasaan merokok pada masyarakat Indonesia. Pengeluaran yang digunakan untuk rokok, secara tidak langsung dapat berakibat buruk bagi balita termasuk kurangnya asupan zat gizi. Namun, hingga saat ini belum diketahui pasti besarnya pengurangan asupan zat gizi balita akibat konsumsi rokok dan paparan asap rokok pasif tersebut.

Tujuan: Mengetahui perbedaan asupan energi dan protein balita berdasarkan konsumsi rokok pada rumah tangga miskin di Kota Yogyakarta.

Metode: Penelitian ini merupakan studi cross sectional dengan subjek penelitian 86 balita usia 2-5 tahun yang tinggal dalam rumah tangga miskin di Kota Yogyakarta. Data konsumsi rokok, karakteristik ibu balita dan seluruh anggota keluarga yang ditanggung diperoleh melalui wawancara. Asupan gizi dinilai menggunakan metode multiple 24 hours food recall selama 4 hari. Analisis statistik dilakukan dengan menggunakan Two Sample Independent t-test, MannWhitney U-test, regresi, dan Chi-Square.

Hasil: Terdapat 77,9\% rumah tangga miskin yang mempunyai setidaknya 1 perokok. Asupan energi dan protein balita tidak berbeda bermakna antara balita yang tinggal dalam rumah tangga miskin dengan perokok, dan tanpa perokok meskipun persentase pengeluaran untuk pangan lebih rendah secara bermakna pada rumah tangga dengan perokok. Hal ini disebabkan sebagian besar balita mengonsumsi sumber energi dan protein dengan harga rendah. Makanan ringan menjadijenis makanan ke-3 terbanyak yang dikonsumsi balita dan $40 \%$ protein hewani yang dikonsumsi balita adalah telur yang merupakan sumber energi dan protein dengan harga terjangkau.

Simpulan: Tidak terdapat perbedaan asupan energi dan protein yang bermakna pada balita yang tinggal di dalam rumah tangga miskin dengan perokok dan tanpa perokok. Namun, terdapat perbedaan bermakna pada persentase pengeluaran pangan, yaitu pengeluaran pangan lebih rendah pada rumah tangga dengan perokok.
\end{abstract}

KATA KUNCI: rumah tangga miskin, rokok, asupan zat gizi, balita, perokok, non-perokok

\footnotetext{
${ }^{1}$ Korespondensi: Sekolah Tinggi Ilmu Kesehatan Alma Ata Yogyakarta, Jl. Ringroad Barat Daya No. 1, Tamantirto, Yogyakarta, e-mail: winda_irwanti@ yahoo.co.id

2 Bagian IImu Kesehatan Anak Rumah Sakit Umum Pusat Dr. Sardjito/Fakultas Kedokteran Universitas Gadjah Mada, JI. Kesehatan No 1 Yogyakarta, e-mail: madarinajulia@yahoo.com

${ }^{3}$ Program Studi S2 IImu Kesehatan Masyarakat, Fakultas Kedokteran Universitas Gadjah Mada, Jl. Farmako, Sekip Utara, Yogyakarta 55281
} 


\section{PENDAHULUAN}

Salah satu agenda Millenium Development Goals (MDG's) 2015 adalah menghilangkan kemiskinan dan kelaparan. Hal ini terkait dengan kemiskinan dan kelaparan yang masih menjadi masalah di negara-negara berkembang termasuk Indonesia. Tercatat 7,5\% penduduk Indonesia tergolong miskin dengan penghasilan di bawah US \$1 per hari (1). Kasus kelaparan (hunger) juga masih ditemukan pada balita di Indonesia dengan prevalensi gizi buruk sebesar $4,9 \%$ dan gizi kurang 13\% (2). Kelaparan ditandai dengan rendahnya asupan zat gizi, diantaranya adalah asupan energi dan protein.

Kemiskinan dan kelaparan diperparah dengan adanya kebiasaan buruk pada masyarakat diantaranya adalah merokok. Sebagian besar $(57 \%)$ rumah tangga di Indonesia mempunyai sedikitnya 1 perokok dalam rumah dan terdapat $73,8 \%$ ayah balita dalam rumah tangga miskin yang merokok $(3,4)$. Menurut survei perilaku merokok yang dilakukan oleh Dinas Kesehatan (Dinkes) Provinsi Daerah Istimewa Yogyakarta (DIY) tahun 2009, terdapat $52,1 \%$ rumah tangga di Kota Yogyakarta yang mempunyai perokok (5). Indonesia menempati urutan kelima di antara negara-negara dengan tingkat agregat konsumsi tembakau tertinggi di dunia. Indonesia juga mengalami peningkatan tajam konsumsi tembakau dalam 30 tahun terakhir, dari 33 miliar batang per tahun pada tahun 1970 meningkat menjadi 217 miliar batang pada tahun 2000 (6). Pada tahun 2010, persentase nasional perokok per hari pada penduduk umur lebih dari 10 tahun adalah $28,2 \%$ sedangkan persentase perokok per hari di Provinsi DIY berada pada angka $25,3 \%$ (2).

Anak-anak turut menanggung dampak secara tidak sengaja atau involuntary dari konsumsi rokok yang dilakukan oleh orang tua dan anggota keluarga lain dalam rumah tangga. Anak-anak mempunyai keterbatasan dalam membatasi paparan rokok baik secara langsung sebagai perokok pasif maupun tidak langsung misalnya dampak ekonomis. Paparan asap rokok pasif yang tertinggi terjadi pada anak umur 0-14 tahun yaitu sekitar $70,6 \%$ (43.018.678 orang) dari total penduduk berumur 0-14 tahun. Hasil mapping perilaku merokok di DIY pada tahun 2009 menunjukkan bahwa sebanyak $55,4 \%$ rumah tangga mempunyai pengeluaran untuk tembakau. Dengan demikian, minimal terdapat 1 anggota keluarga dalam rumah tangga tersebut yang mengonsumsi tembakau (5). Dampak tidak langsung paparan rokok bagi anak antara lain dapat mempengaruhi asupan zat gizi dan status gizi anak, salah satu mekanismenya disebabkan oleh pengeluaran pangan yang rendah akibat dari konsumsi rokok anggota keluarga. Menurut Badan Pusat Statistik (BPS) tahun 2009 , sebesar $5,26 \%$ pengeluaran rumah tangga dialokasikan untuk tembakau dan sirih. Angka ini berada pada urutan ketiga untuk pengeluaran jenis makanan setelah makanan jadi dan padi-padian. Angka ini lebih tinggi dari persentase pengeluaran untuk jenis makanan sumber zat gizi penting seperti ikan $(4,29 \%)$, telur dan susu $(3,27 \%)$, atau kacang-kacangan $(1,57 \%)(6)$.

Penelitian di Indonesia menemukan bahwa setelah mengendalikan variabel jenis kelamin, umur anak, umur ibu, pendidikan, dan pengeluaran per minggu, rumah tangga dengan ayah perokok meningkatkan risiko balita wasting tingkat berat (BB/TB < -3SD) sebesar 1,17 kali $(p<0,01)$, serta meningkatkan risiko balita stunting tingkat berat $(T B / U<-3 S D)$ sebesar 1,15 kali $(p<0,001)$. Penelitian ini juga menemukan bahwa terdapat $34 \%$ balita underweight (BB/U < -3SD) dalam rumah tangga yang mempunyai ayah perokok (4). Namun demikian, hingga saat ini belum banyak penelitian mengenai hubungan konsumsi rokok dalam rumah tangga dengan asupan gizi balita, terutama pada rumah tangga miskin di wilayah Kota Yogyakarta.

Berdasarkan latar belakang masalah tersebut, maka dapat diketahui bahwa konsumsi rokok dapat menyebabkan pengalihan sumber daya dalam rumah tangga yang berakibat pada rendahnya pengeluaran pangan dan rendahnya asupan gizi, termasuk pada balita. Oleh karena itu, peneliti tertarik untuk mengetahui ada tidaknya perbedaan asupan zat gizi energi dan protein pada anak balita usia 2-5 tahun berdasarkan konsumsi rokok pada rumah tangga miskin di Kota Yogyakarta. Tujuan penelitian ini adalah mengetahui rerata jumlah rokok yang dikonsumsi dan pengeluaran untuk rokok pada rumah tangga miskin, mengetahui rerata asupan energi dan protein anak balita pada rumah tangga miskin, dan mengetahui perbedaan asupan energi dan protein anak balita berdasarkan konsumsi rokok pada rumah tangga miskin di Kota Yogyakarta.

\section{BAHAN DAN METODE}

Jenis penelitian ini adalah penelitian analitik dengan rancangan cross sectional yaitu rancangan penelitian yang pengukuran terhadap variabel bebas maupun terikat dilakukan satu kali dan dalam waktu yang bersamaan (7). Rancangan ini digunakan dengan alasan bahwa secara teori, variabel bebas berupa konsumsi rokok dalam rumah tangga memberikan dampak pada variabel terikat berupa asupan zat gizi balita dalam jangka waktu yang pendek atau hampir bersamaan.

Lokasi penelitian adalah daerah dengan jumlah rumah tangga miskin paling banyak di Kota Yogyakarta menurut data Dinas Sosial yaitu Kelurahan Pringgokusuman dan Bumijo. Ruang lingkup lokasi penelitian yang lebih sempit dipilih berdasarkan wilayah rukun warga (RW) dengan jumlah KK miskin terbanyak, yaitu RW 1, 3, 7, dan 9 di Kelurahan Bumijo, serta RW 24 dan 25 di Kelurahan 
Pringgokusuman. Pengambilan data berlangsung pada bulan November 2010 hingga Februari 2011. Populasi penelitian adalah balita usia 2-5 tahun pada rumah tangga miskin di Kota Yogyakarta dengan subjek penelitian adalah seluruh anggota keluarga dan balita usia 2-5 tahun dalam rumah tangga miskin di Kota Yogyakarta. Kriteria inklusi adalah rumah tangga miskin yang tinggal di daerah penelitian, yang mempunyai balita usia 2 - 5 tahun, dan bersedia menjadi subjek penelitian dengan menandatangani informed consent.

Besar sampel dihitung menggunakan rumus untuk satu kelompok sampel dengan tingkat kepercayaan 95\% $(\alpha=0,05)$, nilai presisi (d) sebesar 10\%, dan nilai proporsi balita underweight (berat badan per umur atau BB/U<-2SD) dengan ayah perokok yaitu 34\% sehingga diperoleh jumlah sampel minimal sebesar 86 subjek (8). Data kemiskinan dari Dinas Sosial Kota Yogyakarta digunakan untuk mengetahui rumah tangga yang termasuk dalam kategori miskin. Pengkategorian rumah tangga miskin berdasarkan pada tabel kriteria rumah tangga miskin dari Dinas Sosial yang dinilai dari berbagai aspek yaitu 1) Pendapatan dan Aset; 2) Papan; 3) Pangan; 4) Sandang; 5) Pendidikan; dan 6) Sosial. Metode pemilihan sampel menggunakan quota sampling dengan memperhatikan kriteria inklusi.

Terdapat 4 macam variabel yang diteliti dalam penelitian ini yaitu variabel bebas, terikat, antara, dan luar. Variabel bebas adalah konsumsi rokok dalam rumah tangga yang diperoleh dari wawancara kepada responden ayah dan/atau anggota keluarga lain yang merokok. Konsumsi rokok diukur dari jumlah batang yang dihisap per hari dan harga rokok. Variabel terikat adalah asupan energi dan protein, serta status gizi berdasarkan berat badan terhadap umur (BB/U). Asupan energi dan protein diukur menggunakan metode multiple 24 hours food recall selama 4 hari kepada responden ibu atau pengasuh sedangkan berat badan diperoleh dari pengukuran menggunakan timbangan badan digital yang telah dikalibrasi oleh Badan Metrologi di Yogyakarta. Variabel antara terdiri dari persentase pengeluaran untuk makanan dan paparan asap rokok dalam rumah, serta variabel luar berupa pendidikan ayah dan ibu. Pendidikan dikategorikan menjadi dua yaitu pendidikan rendah jika tidak tamat SMA/sederajat dan pendidikan tinggi jika tamat SMA/sederajat atau perguruan tinggi. Pengambilan data dilakukan oleh peneliti dibantu oleh 4 orang enumerator yang merupakan lulusan S1 Jurusan Gizi Kesehatan.

Analisis data asupan energi dan protein diolah menggunakan software nutrisurvey. Uji statistik yang dilakukan adalah uji Two Sample Independent t-test, Mann-Whitney U-test, regresi, dan Chi-Square dengan menggunakan software stata. Etika penelitian berupa persetujuan dari Komite Etik Universitas Gadjah Mada dan penandatanganan informed consent oleh responden sebagai bukti kesediaan berpartisipasi.

\section{HASIL}

Rata-rata umur subjek penelitian adalah 40,12 \pm 10,86 bulan. Seluruh rumah tangga termasuk dalam rumah tangga miskin menurut kriteria Dinas Sosial, rerata skor kemiskinan sebesar 55,39 \pm 4,05 dengan skor minimal 51 dan skor maksimal 68. Karakteristik dasar ayah dan ibu dari 86 subjek balita terdiri atas 85 ayah dan 85 ibu karena terdapat 1 orang ayah dan 1 orang ibu yang meninggal dunia. Sebagian besar ibu dan ayah dari subjek mempunyai tingkat pendidikan yang rendah (54\% untuk ibu dan $58 \%$ untuk ayah). Pekerjaan ayah yang paling banyak adalah sebagai karyawan swasta, wiraswasta, dan buruh dengan persentase yang sama (33\%) sedangkan sebagian besar ibu merupakan ibu rumah tangga (57\%).

Hasil penelitian menunjukkan bahwa dari 86 rumah tangga miskin yang menjadi responden, sebanyak 77,9\% rumah tangga mempunyai setidaknya 1 orang perokok. Jumlah perokok mulai dari 1 hingga 6 orang perokok, dengan frekuensi 1 perokok sebanyak 52 rumah tangga $(60,5 \%), 2$ perokok sebanyak 13 rumah tangga $(15,1 \%)$, 3 perokok sebanyak 1 rumah tangga $(1,2 \%)$, dan 6 perokok sebanyak 1 rumah tangga (1,2\%). Jenis rokok yang paling banyak dikonsumsi adalah rokok jenis kretek. Median jumlah batang rokok yang dikonsumsi per hari adalah sebesar 10 batang. Median biaya yang digunakan untuk konsumsi rokok per rumah tangga adalah sebesar Rp 165.000,- yang merupakan 13,4\% dari pengeluaran total.

Tabel 1 menunjukkan adanya perbedaan yang bermakna antara konsumsi rokok dengan persentase pengeluaran pangan. Persentase pengeluaran pangan pada rumah tangga dengan perokok lebih rendah secara bermakna bila dibandingkan rumah tangga tanpa perokok dan selisih perbedaan ini adalah sebesar 6,1\%. Pola hubungan yang sama terjadi pada konsumsi rokok dan persen pengeluaran pangan per kapita. Namun, hasil penelitian menunjukkan tidak adanya perbedaan yang bermakna antara asupan energi dan protein balita yang tinggal dalam rumah tangga dengan perokok dan rumah tangga tanpa perokok (Tabel 1). Asupan energi balita pada rumah tangga dengan perokok menunjukkan nilai median $1.052,2 \mathrm{kkal} / \mathrm{hari}$ sedangkan pada rumah tangga tanpa perokok menunjukkan nilai median yang lebih rendah yaitu 961,8 kkal/hari. Demikian juga dengan asupan protein balita pada rumah tangga tanpa perokok yang lebih rendah yaitu sebesar 31,2 gram/hari dibandingkan rumah tangga dengan perokok yang menunjukkan nilai rerata 34,4 gram/ hari. Tingkat pendidikan dan jenis pekerjaan ibu maupun ayah juga tidak menunjukkan perbedaan bermakna antara rumah tangga dengan perokok maupun tanpa perokok.

Tabel 2 menyajikan analisis perbedaan karakteristik antara rumah tangga dengan perokok dan rumah tangga tanpa perokok yang jenis datanya bersifat kategori. Tabel 
Tabel 1. Analisis Two Sample Independent t-test dan Mann-Whitney U-test perbedaan rumah tangga dengan perokok dan rumah tangga tanpa perokok

\begin{tabular}{|c|c|c|c|c|c|}
\hline Karakteristik & Satuan & $\begin{array}{l}\text { Rumah tangga } \\
\text { dengan perokok } \\
(n=67)\end{array}$ & $\begin{array}{l}\text { Rumah tangga } \\
\text { tanpa perokok } \\
\quad(n=19)\end{array}$ & $\begin{array}{l}\text { Mean difference } \\
(95 \% \mathrm{Cl})\end{array}$ & $\mathbf{p}$ \\
\hline $\begin{array}{l}\text { Skor kemiskinan } \\
(\text { mean } \pm \mathrm{SD})^{\neq}\end{array}$ & & $55,8 \pm 4,7$ & $54,3 \pm 3,7$ & $\begin{array}{l}1,5 \\
(-0,6 ; 3,5)\end{array}$ & 0,06 \\
\hline $\begin{array}{l}\text { Total pengeluaran rumah tangga per bulan } \\
(\text { mean } \pm \mathrm{SD})^{\neq}\end{array}$ & rupiah & $1.478 .799 \pm 529.496$ & $1.172 .692 \pm 443.768$ & $\begin{array}{l}306.106 \\
(60.964 ; 551.248)\end{array}$ & $0,02^{*}$ \\
\hline $\begin{array}{l}\text { Total pengeluaran per kapita per bulan } \\
(\text { mean } \pm \mathrm{SD})^{\neq}\end{array}$ & rupiah & $356.141 \pm 143.500$ & $276.212 \pm 97.286$ & $\begin{array}{l}79.929 \\
(22.679 ;-137.179)\end{array}$ & $0,01^{*}$ \\
\hline $\begin{array}{l}\text { Pengeluaran pangan per bulan } \\
\text { rumah tangga }(\text { mean } \pm S D)^{\neq}\end{array}$ & rupiah & $844.813 \pm 39.255$ & $869.276 \pm 88.250$ & $\begin{array}{l}-24.462 \\
(-198.232 ; 149.306)\end{array}$ & 0,39 \\
\hline $\begin{array}{l}\text { Persentase pengeluaran pangan } \\
\text { dibandingkan dengan pengeluaran total } \\
\text { per bulan rumah tangga (mean } \pm S D)^{\neq}\end{array}$ & $\%$ & $66,2 \pm 15,9$ & $60,1 \pm 11,9$ & $\begin{array}{l}-6,1 \\
(-12,6 ; 0,5)\end{array}$ & $0,03^{*}$ \\
\hline $\begin{array}{l}\text { Pengeluaran pangan per bulan } \\
\text { per kapita }(\text { mean } \pm \mathrm{SD})^{\neq}\end{array}$ & rupiah & $201.759 \pm 10.658$ & $213.167 \pm 17.800$ & $\begin{array}{l}-11.408 \\
(-55.481 ; 32.664)\end{array}$ & 0,30 \\
\hline $\begin{array}{l}\text { Persentase pengeluaran pangan } \\
\text { dibandingkan dengan pengeluaran total } \\
\text { per bulan per kapita } \\
{[\text { median }(\mathrm{Q} 1 ; \mathrm{Q} 3)]^{\neq \neq}}\end{array}$ & $\%$ & $\begin{array}{l}14,7 \\
(10,9 ; 18,7)\end{array}$ & $\begin{array}{l}17,3 \\
(10,3-25,4)\end{array}$ & & $0,04^{*}$ \\
\hline $\begin{array}{l}\text { Jumlah anggota keluarga } \\
(\text { mean } \pm S D)^{\ddagger}\end{array}$ & orang & $4,4 \pm 0,14$ & $4,3 \pm 0,4$ & $\begin{array}{l}0,1 \\
(-0,5 ; 0,8)\end{array}$ & 0,66 \\
\hline $\begin{array}{l}\text { Asupan energi balita } \\
{[\text { median }(\mathrm{Q} 1, \mathrm{Q} 3)]^{\neq \neq}}\end{array}$ & kkal & $\begin{array}{l}1.052,2 \\
(850,6-1251,6)\end{array}$ & $\begin{array}{l}961,8 \\
(752,3-1147,3)\end{array}$ & & 0,89 \\
\hline $\begin{array}{l}\text { Asupan protein balita } \\
(\text { mean } \pm \mathrm{SD})^{\neq}\end{array}$ & gram & $34,4 \pm 1,2$ & $31,2 \pm 2,1$ & $\begin{array}{l}3,1 \\
(-1,8-8,1)\end{array}$ & 0,20 \\
\hline $\begin{array}{l}\text { Status gizi berdasarkan nilai } \\
\text { z-score BB/U }(\text { mean } \pm \mathrm{SD})^{\neq}\end{array}$ & & $-1,4 \pm 1,2$ & $-1,1 \pm 1,5$ & $\begin{array}{l}-0,31 \\
(-0,9 ; 0,3)\end{array}$ & 0,33 \\
\hline
\end{tabular}

Keterangan : : analisis menggunakan Two Sample Independent t test

$\neq \neq$ analisis menggunakan Mann Whitney U-test

* bermakna $(p<0,05)$

Tabel 2. Analisis Chi-Square perbandingan antara rumah tangga dengan perokok dan rumah tangga tanpa perokok

\begin{tabular}{|c|c|c|c|c|c|}
\hline Karakteristik & $\begin{array}{c}\text { Rumah tangga dengan } \\
\text { perokok } \\
(\mathrm{n}=67)\end{array}$ & $\begin{array}{c}\text { Rumah tangga tanpa } \\
\text { perokok } \\
(\mathrm{n}=19)\end{array}$ & $x^{2}$ & $\begin{array}{l}\text { Prevalence ratio } \\
(95 \% \mathrm{Cl})\end{array}$ & $\mathbf{p}$ \\
\hline \multicolumn{6}{|l|}{ Pendidikan ayah } \\
\hline $\begin{array}{l}\text { Rendah } \\
\text { Tinggi }\end{array}$ & $\begin{array}{l}38(57 \%) \\
29(43 \%)\end{array}$ & $\begin{array}{l}11(61 \%) \\
7(39 \%)\end{array}$ & 0,11 & $\begin{array}{c}0,83 \\
(0,28-2,41)\end{array}$ & 0,47 \\
\hline \multicolumn{6}{|l|}{ Pendidikan ibu } \\
\hline $\begin{array}{l}\text { Rendah } \\
\text { Tinggi }\end{array}$ & $\begin{array}{l}36(54 \%) \\
30(46 \%)\end{array}$ & $\begin{array}{l}10(53 \%) \\
9(47 \%)\end{array}$ & 0,02 & $\begin{array}{c}1,08 \\
(0,38-3,00)\end{array}$ & 0,54 \\
\hline \multicolumn{6}{|l|}{ Pekerjaan ibu } \\
\hline $\begin{array}{l}\text { Karyawan swasta/wiraswasta } \\
\text { Buruh } \\
\text { lbu rumah tangga }\end{array}$ & $\begin{array}{c}19(29 \%) \\
7(10 \%) \\
40(61 \%)\end{array}$ & $\begin{array}{l}7(37 \%) \\
3(16 \%) \\
9(47 \%)\end{array}$ & 1,09 & & 0,57 \\
\hline \multicolumn{6}{|l|}{ Pekerjaan ayah } \\
\hline $\begin{array}{l}\text { Pegawai honorer/ karyawan } \\
\text { swasta/ wiraswasta } \\
\text { Buruh }\end{array}$ & $\begin{array}{l}44(66 \%) \\
23(37 \%)\end{array}$ & $\begin{array}{l}13(72 \%) \\
5(28 \%)\end{array}$ & 0,27 & $\begin{array}{c}1,35 \\
(0,43-4,2)\end{array}$ & 0,60 \\
\hline $\begin{array}{l}\text { Asupan energi balita } \\
\quad<80 \% \text { AKG } \\
\quad \geq 80 \% \text { AKG }\end{array}$ & $\begin{array}{l}34(51 \%) \\
33(49 \%)\end{array}$ & $\begin{array}{l}13(68 \%) \\
6(32 \%)\end{array}$ & 1,86 & $\begin{array}{c}0,47 \\
(0,16-1,39)\end{array}$ & 0,20 \\
\hline $\begin{array}{l}\text { Asupan protein balita } \\
\quad<80 \% \text { AKG } \\
\quad \geq 80 \% \text { AKG }\end{array}$ & $\begin{array}{l}14(21 \%) \\
53(79 \%)\end{array}$ & $\begin{array}{c}4(21 \%) \\
15(79 \%)\end{array}$ & 0,00 & $\begin{array}{c}0,99 \\
(0,28-3,45)\end{array}$ & 0,60 \\
\hline
\end{tabular}

Keterangan: $A K G$ = angka kecukupan gizi rekomendasi Widya Karya Pangan dan Gizi, 2004 
Tabel 3. Analisis Two Sample Independent t-test jenis makanan yang dikonsumsi balita (g/hari)

\begin{tabular}{lcccc}
\hline \multicolumn{1}{c}{ Jenis makanan } & Seluruh balita & $\begin{array}{c}\text { Balita pada rumah } \\
\text { tangga dengan perokok }\end{array}$ & $\begin{array}{c}\text { Balita pada rumah tangga } \\
\text { tanpa perokok }\end{array}$ & p \\
\hline Makanan pokok & $256,2 \pm 91,2$ & $257,4 \pm 90,3$ & $252,1 \pm 96,5$ & 0,83 \\
Protein hewani & $66,2 \pm 33,9$ & $68,8 \pm 4,0$ & $57,0 \pm 32,7$ & 0,18 \\
Protein nabati & $20,0 \pm 19,6$ & $19,6 \pm 18,5$ & $21,4 \pm 23,6$ & 0,76 \\
Susu & $33,4 \pm 27,4$ & $34,8 \pm 28,9$ & $28,3 \pm 34,8$ & 0,55 \\
Sayur & $21,7 \pm 17,3$ & $20,6 \pm 16,1$ & $25,6 \pm 21,0$ & 0,35 \\
Buah & $20,1 \pm 37,1$ & $21,9 \pm 39,9$ & $13,8 \pm 24,2$ & 0,28 \\
Makanan ringan rasa & $41,7 \pm 26,8$ & $40,8 \pm 27,7$ & $44,7 \pm 23,8$ & 0,27 \\
manis dan gurih & & & & \\
Gula & $7,2 \pm 6,1$ & $7,7 \pm 6,6$ & $5,2 \pm 3,2$ & $0,02^{*}$ \\
Minyak/santan & $9,8 \pm 6,6$ & $9,2 \pm 6,0$ & $11,0 \pm 8,0$ & 0,22 \\
\hline
\end{tabular}

Keterangan: * bermakna $(p<0,05)$

2 menunjukkan bahwa tidak terdapat hubungan bermakna antara tingkat pendidikan dan pekerjaan ayah maupun ibu dengan status merokok dalam rumah tangga. Tingkat asupan energi dan protein balita juga tidak berhubungan bermakna dengan status merokok dalam rumah tangga miskin. Tabel 3 menunjukkan bahwa secara keseluruhan, makanan pokok, protein hewani, dan makanan ringan manis maupun gurih menempati urutan terbesar pada jenis makanan yang paling banyak dikonsumsi oleh balita dalam penelitian ini.

\section{BAHASAN}

Hasil penelitian menunjukkan bahwa persentase rumah tangga miskin dengan perokok adalah sebesar $77,9 \%$. Angka ini lebih tinggi bila dibandingkan dengan hasil penelitian sebelumnya yang menyatakan bahwa di Indonesia terdapat lebih dari setengah (57\%) rumah tangga mempunyai sedikitnya 1 perokok dalam rumah dan hasil survei menunjukkan terdapat 55\% rumah tangga dengan perokok di Kota Yogyakarta $(3,5)$. Penelitian di Republik Czech menyatakan bahwa dari 1.061 rumah tangga, terdapat 58,4\% rumah tangga dengan minimal 1 perokok (9). Hal ini sesuai dengan hasil penelitian yang menyatakan bahwa pada beberapa negara, yaitu di India, Cina, Brazil, Mexico, Vietnam, Guatemala, Polandia, Hungaria, Afrika Selatan, dan Kosta Rika, prevalensi konsumsi tembakau pada masyarakat miskin lebih tinggi bila dibandingkan dengan masyarakat kaya (10). Frekuensi jumlah perokok antara $1-6$ perokok pada satu rumah tangga dan hasil penelitian ini tidak jauh berbeda dengan frekuensi jumlah perokok pada penelitian di Republik Czech yaitu antara 1 hingga 5 perokok, dengan frekuensi tertinggi pada 1 perokok $(30,1 \%)(11)$. Pada penelitian ini, frekuensi tertinggi juga terdapat pada 1 perokok $(60,5 \%)$ dan didominasi oleh ayah.

Median persentase pengeluaran untuk rokok dibandingkan dengan pengeluaran total sebesar $13,4 \%$. Hasil ini lebih tinggi jika dibandingkan dengan rerata persentase pengeluaran rokok pada rumah tangga miskin di negara-negara baru merdeka di kawasan Rusia (Azerbaijan, Georgia, Kazakhstan, Krgyzstan, Russian Federation, dan Tajikistan). Di negara-negara tersebut, persentase pengeluaran untuk tembakau dibandingkan dengan total pengeluaran rumah tangga adalah sebesar $0,53 \%$ sampai dengan 3,28\% (11). Di Bangladesh, pengeluaran untuk tembakau adalah sebesar $6 \%$ pada rumah tangga yang paling miskin dan $1,8 \%$ pada rumah tangga terkaya (12).

Pengeluaran untuk pangan pada rumah tangga dengan perokok menunjukkan persentase yang lebih rendah bila dibandingkan rumah tangga tanpa perokok, dengan selisih persentase sebesar 6,06\% $(p<0,05)$. Hasil ini sesuai dengan penelitian di Bangladesh yang menyatakan bahwa rerata pengeluaran yang digunakan untuk makanan $(56,6 \%)$ lebih rendah pada rumah tangga yang mengonsumsi tembakau bila dibandingkan dengan rumah tangga yang tidak mengonsumsi tembakau (58\%) (12). Hal ini membuktikan bahwa pada rumah tangga dengan perokok cenderung mengalihkan dana konsumsi pangan rumah tangga untuk konsumsi rokok.

Hasil penelitian ini menunjukkan bahwa asupan zat gizi energi dan protein pada balita berdasarkan konsumsi rokok rumah tangga tidak menunjukkan perbedaan bermakna. Hasil ini tidak sesuai dengan hipotesis awal yang menyatakan bahwa terdapat perbedaan asupan zat gizi energi dan protein balita berdasarkan konsumsi rokok rumah tangga terkait dengan persentase pengeluaran untuk pangan. Hasil penelitian ini menunjukkan bahwa meskipun persentase pengeluaran untuk pangan lebih rendah pada rumah tangga dengan perokok, hal tersebut tidak menyebabkan asupan energi dan protein balita pada rumah tangga dengan perokok lebih rendah.

Ketidaksesuaian hasil ini disebabkan oleh beberapa hal, diantaranya adalah biaya pangan (food cost) dari makanan sumber energi dan protein yang tergolong rendah. Artinya, baik pada rumah tangga perokok maupun tanpa perokok, keduanya dapat menjangkau makanan 
sumber energi dan protein karena harganya yang relatif rendah. Penelitian di Brazil terhadap 346 anak usia 3-4 tahun dengan status sosial ekonomi keluarga yang rendah menunjukkan bahwa konsumsi energi yang diperoleh dari makanan kaya gula dan lemak (sugar rich food / SRF dan fat rich food / FRF) tidak berhubungan dengan pengeluaran untuk pangan (food expenditure). Hal ini terjadi karena makanan yang kaya energi tersebut mudah dijangkau meskipun dengan finansial yang terbatas $(13,14)$. Penelitian di Inggris juga menyatakan bahwa dalam keluarga berpendapatan rendah dengan ibu yang berpendidikan rendah, ibu akan lebih sering menawarkan makanan yang kaya lemak dan energi (15). Menurut data United States Department of Agriculture (USDA), keluarga dengan pendapatan rendah cenderung mengonsumsi makanan dengan harga murah dan tinggi energi (16). Uraian ini membuktikan bahwa asupan makan balita pada penelitian ini cenderung tinggi kandungan energi dan protein karena harganya yang relatif murah sehingga berpotensi rendah kandungan zat gizi lain, contohnya zat gizi mikro (berbagai jenis vitamin, zat besi, seng, folat, magnesium) yang sangat penting bagi pertumbuhan dan perkembangan balita.

Kemungkinan rendahnya asupan zat gizi mikro pada balita yang tinggal dalam rumah tangga dengan pengeluaran pangan yang rendah didukung oleh banyak penelitian, diantaranya penelitian di Brazil yang menunjukkan bahwa semakin tinggi pengeluaran pangan maka semakin tinggi pula asupan zat gizi mikro seperi zat besi, seng, vitamin $A$, dan vitamin $C$ (17). Praktik pemberian makan pada keluarga dengan pendapatan rendah dikaitkan dengan ketidakcukupan asupan mikronutrien dan tingginya konsumsi makanan tinggi energi yang menjelaskan tingginya anemia (16), hipovitaminosis A, dan malnutrisi mikronutrien lain, juga obesitas pada anak prasekolah di Brazil (18). Hasil penelitian di Inggris, anak remaja yang tinggal bersama orang tua perokok mempunyai pola makan yang berbeda dibandingkan anak remaja yang tinggal bersama orang tua non perokok. Perbedaan ini terletak pada lebih rendahnya asupan serat, vitamin $C$, vitamin $E$, folat, dan magnesium sejalan dengan rendahnya konsumsi jus buah, roti wholemeal, dan beberapa sayuran pada anak remaja yang tinggal bersama orang tua perokok. Anak remaja yang tinggal bersama orang tua perokok mempunyai pola makan yang mirip dengan anak remaja yang merokok (19). Lingkungan dengan paparan asap rokok (environmental tobacco smoke/ETS) pada anak usia 2 - 12 tahun juga dapat mengurangi konsentrasi asam askorbat (vitamin C) dalam darah anak (20).

Terkait dengan bahasan bahwa penyebab tidak adanya perbedaan asupan energi dan protein pada balita adalah terjangkaunya harga makanan sumber energi dan protein baik oleh rumah tangga dengan perokok maupun tanpa perokok, maka dalam penelitian ini dilakukan analisis jenis makanan yang dikonsumsi balita. Secara keseluruhan, makanan pokok, protein hewani, dan makanan ringan manis maupun gurih menempati urutan terbesar dari jenis makanan yang paling banyak dikonsumsi oleh balita dalam penelitian ini. Makanan ringan yang paling banyak dikonsumsi adalah makanan ringan dengan rasa manis $(72 \%)$ yang berarti kandungan gulanya tinggi. Hasil penelitian di Amerika Serikat menyebutkan bahwa terdapat hubungan yang berkebalikan antara densitas energi (kandungan energi per gram) dalam makanan $(\mathrm{kJ} / \mathrm{g})$ dan biaya energi ( $\$ / \mathrm{MJ})$. Densitas energi yang tinggi pada serealia, lemak, dan makanan manis merepresentasikan pilihan diit dengan biaya terendah dari konsumen. Rasa dan tekstur yang enak, harga yang rendah dari makanan tinggi densitas energi, ditambah dengan banyaknya porsi dan rendahnya kemampuan untuk mengenyangkan (low satiety), dapat menjadi alasan bagi makan berlebihan dan peningkatan berat badan (14). Dalam populasi umum, konsumen memilih makanan berdasarkan rasa, harga, tekstur (kesenangan), kesehatan, dan variasi. Dalam rumah tangga dengan pendapatan rendah, rasa dan harga adalah determinan kunci dalam memilih makanan (14).

Protein hewani yang paling banyak dikonsumsi oleh balita pada penelitian ini adalah telur (40,1\%). Penelitian di Amerika Serikat menyebutkan bahwa contoh makanan yang menyediakan energi dengan harga murah adalah lemak, gula, sereal, serta produk daging dan protein harga rendah (14). Di Kota Yogyakarta sebagai ruang lingkup populasi pada penelitian ini, telur termasuk dalam sumber protein hewani dengan harga yang relatif murah bila dibandingkan dengan sumber protein hewani lainnya.

Sebagian besar jenis makanan yang dikonsumsi balita tidak menunjukkan perbedaan bermakna antara rumah tangga dengan maupun tanpa perokok. Hal ini membuktikan bahwa pola makan keseluruhan balita pada lingkungan tersebut cenderung sama, baik pada rumah tangga dengan maupun tanpa perokok. Hal inilah yang menjadi penyebab tidak adanya perbedaan asupan energi dan protein balita dalam rumah tangga dengan perokok maupun tanpa perokok. Tidak adanya perbedaan ini dapat juga disebabkan oleh faktor pemberian bantuan makanan tambahan dari pemerintah untuk balita yang mengalami gizi buruk $(\mathrm{BB} / \mathrm{U}<-3)$. Adapun bantuan yang diberikan berupa $300 \mathrm{~g}$ susu; 10 butir telur; 0,5 kg kacang hijau; $0,25 \mathrm{~kg}$ teri; $0,5 \mathrm{~kg}$ beras/bihun/mie telur; $0,5 \mathrm{~kg}$ gula jawa; dan 12 sachet bubur bayi. Bantuan ini diberikan setiap bulannya pada balita yang mempunyai status gizi buruk $(B B / U<-3)$ sebanyak 3 kali berturut-turut dan dihentikan apabila status gizi balita sudah mencapai gizi baik.

Status gizi balita berdasarkan berat badan terhadap umur $(B B / U)$ tidak menunjukkan perbedaan yang bermakna pada kedua kelompok rumah tangga dengan maupun tanpa perokok. Namun, terlihat kecenderungan 
bahwa rerata nilai z-score balita berdasarkan BB/U lebih rendah pada rumah tangga dengan perokok $(-1,4 \pm 1,2)$ bila dibandingkan dengan rumah tangga tanpa perokok $(-1,1 \pm 1,5)$. Hasil ini sesuai dengan penelitian yang menunjukkan bahwa rumah tangga dengan ayah maupun ibu perokok bukan merupakan risiko dari balita mengalami underweight (status gizi BB/U rendah). Penelitian tersebut menyatakan bahwa rumah tangga dengan ayah perokok tidak meningkatkan risiko balita underweight, tetapi meningkatkan risiko balita wasting tingkat berat (BB/TB $<-3 S D)$ sebesar 1,17 kali $(p<0,01)$ serta meningkatkan risiko balita stunting tingkat berat (TB/U < -3SD) sebesar 1,15 kali $(p<0,001)(4)$.

\section{SIMPULAN DAN SARAN}

Asupan energi balita antara rumah tangga miskin dengan perokok dan tanpa perokok tidak menunjukkan perbedaan bermakna. Namun, terdapat perbedaan bermakna pada pengeluaran untuk pangan, yaitu lebih rendah secara bermakna pada rumah tangga dengan perokok. Hal ini menunjukkan bahwa terjadi pengalihan sumber daya dalam rumah tangga dengan perokok yang seharusnya dapat digunakan untuk pangan tetapi justru digunakan untuk konsumsi rokok.

Tidak bermaknanya perbedaan asupan energi dan protein antara rumah tangga dengan perokok dan tanpa perokok disebabkan oleh kedua zat gizi makro ini dapat diperoleh dari sumber-sumber bahan pangan dengan harga murah sehingga dapat dijangkau oleh rumah tangga dengan perokok maupun tanpa perokok. Keadaan ini dapat berpotensi menyebabkan rendahnya asupan zat gizi mikro dalam rumah tangga karena lebih tingginya harga-harga pangan sumber zat gizi mikro tersebut.

Bagi Pemerintah dan Dinas Kesehatan Kota Yogyakarta, diharapkan dapat meningkatkan kampanye anti rokok dan edukasi pada masyarakat (misalnya penyuluhan melalui puskesmas keliling, pencanangan program berhenti merokok atau mengurangi rokok bersama yang berkomitmen sampai ke tingkat RW) supaya lebih banyak mengalokasikan dana rumah tangganya untuk asupan gizi yang berkualitas bagi anaknya dibandingkan untuk merokok. Bagi kader-kader kesehatan yang berhubungan langsung dengan masyarakat, agar dapat memberikan edukasi kepada masyarakat melalui penyuluhan (terutama ibu sebagai pengolah makanan dan ayah sebagai kepala keluarga) mengenai pilihan bahan pangan dan makanan yang terdapat di lingkungan mereka sendiri yang mengandung gizi lengkap untuk balita, baik gizi makro maupun mikro. Perlu dilakukan penelitian lebih lanjut mengenai hubungan konsumsi rokok dalam rumah tangga dengan asupan zat gizi mikro pada balita dan yang tidak kalah penting adalah dampaknya bagi pertumbuhan dan perkembangan balita.

\section{RUJUKAN}

1. UN. Let speak out for MDG's: achieving the millenium development goals in Indonesia. Jakarta: United Nations; 2007.

2. Depkes. Riset Kesehatan Dasar 2010. Jakarta: Badan Penelitian dan Pengembangan Kesehatan, Departemen Kesehatan Indonesia; 2010.

3. Pradono, Kristanti. Passive smokers, the forgotten disaster. Jakarta: National Institute of Health Research and Development, Ministry of Health; 2002.

4. Semba RD, Kalm LM, de Pee S, Ricks MO, Sari M, Bloem MW. Paternal smoking is associated with increased risk of child malnutrition among poor urban families in Indonesia. Public Health Nutr 2007;10(1):7-15.

5. Dinkes Provinsi DIY. Mapping perilaku merokok rumah tangga di Provinsi DIY tahun 2009. Yogyakarta: Dinas Kesehatan Provinsi DIY; 2009.

6. BPS. Pengeluaran rata-rata per kapita sebulan menurut kelompok barang, 1999, 2002-2009. [series online] 2009 [cited 2010 Jun 6]. Available from: URL: http.//www.bps.go.id

7. Sastroasmoro S, Ismael S. Dasar-dasar metodologi penelitian klinis. Jakarta: Binarupa Aksara; 1995.

8. Lemeshow S, Hosmer DW, Klar J, Lwangan SK. Adequacy of sample size in health studies. New York: The World Health Organization and John Wiley and Sons; 1990.

9. Dostál M, Milcová A, Binková B, Kotesovec F, Nozicka J, Topinka J, Srám RJ. Environmental tobacco smoke exposure in children in two district of the Czech Republic. Int J Hyg Environ Health 2008;211(3-4):318-25.

10. Bobak M, Jha P, Nguyen S, Jarvis M. Tobacco control in developing countries. London: Oxford University Press; 2000.

11. Djibuti M, Gotsadze G, Mataradze G, Zoidze A. Influence of household demographic and socioeconomic factors on household expenditure on tobacco in six New Independent States. BMC Public Health 2007;7:222-9.

12. Best CM, Sun K, de Pee S, Bloem MW, Stallkamp G, Semba RD. Parental tobacco use is associated with increased risk of child malnutrition in Bangladesh. Nutrition 2007;23(10):731-8.

13. Monteiro CA, Conde WL, Lu B, Popkin BM. Obesity and inequities in health in the developing world. Int $\mathrm{J}$ Obes Relat Metab Disord 2004;28(9):1181-6.

14. Drewnowski A, Darmon N. Food choices and diet costs: an economic analysis. J Nutr 2005;135(4):900-4.

15. Cooke LJ, Wardle J, Gibson EL, Sapochnik M, Sheiham A, Lawson M. Demographic, familial and trait predictors of fruit and vegetable consumption by pre-school children. Public Health Nutr 2004;7(2):295-302.

16. Kaufman PR, MacDonald JM, Lutz SM, Smallwood DM. Do the poor pay more for food? Item selection 
and price difference affect low income household food costs. Washington, DC: United States Department of Agriculture (report no. 759); 1997.

17. Rauber F, Vitolo MR. Nutritional quality and food expenditure in preschool children. J Pediatr (Rio J) 2009;85(6):536-40.

18. Vieira AC, Diniz AS, Cabral PC, Oliveira RS, Lóla MM, Silva SM, Kolsteren P. Nutritional assessment of iron status and anemia in children under 5 years old at public daycare centers. J Pediatr (Rio J) 2007;83(4):370-6.

19. Crawley HF, While D. Parental smoking and the nutrient intake and food choice of British teenagers aged 16-17 years. J Epidemiol Community Health 1996;50(3):306-12.

20. Preston AM, Rodriguez C, Rivera CE, Sahai $H$. Influence of environmental tobacco smoke on vitamin C status in children. Am J Clin Nutr 2003;77(1):167-72. 